\title{
Boeninger, Oakeshott
}

\section{y el estudio de los clásicos}

CAdA Uno EN SU CAMPo y a SU MANERA, Edgardo Boeninger y Michael Oakeshott tuvieron una influencia formativa tanto sobre el carácter como sobre el tenor y disposición política en Chile y en Gran Bretaña en momentos excepcionalmente difíciles en la vida de ambas naciones. Es muy improbable que las grandes reformas adelantadas por la Sra. Thatcher se hubieran realizado en la ausencia de la fundamentación intelectual y política con que el eminente filósofo contribuyó a fortalecer el espinazo moral de su patria. Esta contribución fue reconocida legendariamente cuando la misma Sra. Thatcher ofreció al austero pensador su elevación al grado de caballero, ofrecimiento que este declinó con elegante cortesía. Es asimismo imposible desconocer la enorme importancia que la sensatez, pragmatismo y entereza moral de Edgardo Boeninger tuvieron en reiterar y fortalecer la elevación de miras y el compromiso con la libertad de pensamiento tanto desde la rectoría de la Universidad de Chile como de los influyentes cargos que desempeñó en varios gobiernos de la nación.

Menos conocido es el hecho de que Boeninger y Oakeshott compartían un interés que, dependiendo del punto de vista del observador, puede ser extraordinariamente desconcertante $o$ abrir la puerta a la comprensión de aspectos decidores de la personalidad de los dos pensadores. Aquí cabe explicar que en 1951, cuando la London School of Economics and Political Science invito a Michael Oakeshott a ocupar la cátedra de filosofía política vacante después de la muerte del fogueado intelectual izquierdista Harold Laski, su curriculum incluía dos libros, Experience and Its Modes, aparecido en 1933 (aún en prensa, setenta y ocho años más tarde) y The Study of the 
Classics, publicado en 1936. El primero es un importante tratado filosófico; el segundo es un estudio de los clásicos del calendario hípico inglés. Ocurre que tanto Oakeshott como Boeninger dedicaron tiempo, energía mental e infinita paciencia al estudio sistemático y al goce apasionado de las carreras de caballos. Oakeshott apostaba, no mucho, pero lo suficiente para acicatear su interés por la hípica. Por lo menos cuando yo le conocí, hacia la década de 1960, Boeninger no apostaba, pero es posible que esa severa abstinencia haya cedido algo con el transcurso del tiempo.

Maria Sharapova y Franklin Delano Roosevelt optaron por la filatelia; Luis XVI por la cerrajería; Churchill levantaba muros de ladrillo con precisión obsesiva; Gladstone prefería talar arboles a hachazos y Anthony Trollope no perdía ocasión para cabalgar a la caza del zorro por esos campos ingleses. La importancia de los hobbies no está en duda, pero al misterio de sus orígenes es necesario agregarle la impenetrable confusión que le han echado encima los discípulos del Dr. Freud. Sin embargo, habiendo sido alumno de Michael Oakeshott y colega y amigo de Edgardo Boeninger, voy a aventurar una explicación que me parece compatible con los hechos aun cuando amablemente aventurada. Creo que lo que caracterizó a Boeninger y Oakeshott fue una apreciación extraordinariamente perceptiva de la naturaleza del riesgo en los asuntos humanos tanto en sus aspectos intimidatorios como en su papel protagónico como acompañante obligatorio de todos nuestros intentos por construir o predecir el futuro. Enfrentados el uno con las delicias predictivas de los econometristas y consultores de moda y el otro con la arrogancia de aquella primera saca de ingenieros sociales británicos, optaron ambos por moderar entusiasmos excesivos mediante la aplicación del escepticismo sosegado y constructivo característico de sus tareas académicas y gubernamentales. No es imposible conjeturar que en los hipódromos daban rienda suelta a los riesgos que mantenían estrictamente controlados en los claustros y despachos ministeriales. Tal experiencia seguramente renovaba sus dudas acerca de las virtudes predictivas de modelos matemáticos y esquemas ideológicos sabedores de que el mismo intelecto humano que afirmaba saber precisamente lo que ocurriría en Chile o Gran Bretaña en cinco, diez o veinte 
años era incapaz de predecir el resultado de la quinta carrera en Ascot o el Club Hípico.

Tanto el filósofo inglés como el estadista chileno compartían una apreciación dinámica y eminentemente positiva de la importancia que la disposición y la capacidad de asumir riesgos tuvieron en los orígenes de la Revolución Industrial progenitora de nuestra modernidad. Ambos asimismo coincidían en pensar que esta especie de audacia racional e imaginativa era condición sine qua non para liberar el individualismo creativo necesario para percibir y multiplicar las innovaciones, las nuevas empresas, las inversiones, adelantos, reorganizaciones y cambios constantes sobre los cuales descansa la prosperidad económica de una nación. Es por consiguiente particularmente oportuno y auspicioso recordar el papel principal que tanto el pensamiento de Oakeshott como el apoyo de Boeninger tuvieron en la creación del Instituto de Estudios Internacionales. Edgardo Boeninger fue Rector de nuestra Universidad a fines de la década de 1960, cuando nuestro Instituto aventuraba sus primeros pasos en el ámbito internacional mediante dos principales iniciativas, el Seminario de Arica, en 1968, y la Conferencia del Pacífico, en 1970. Ambas eran decididamente riesgosas; ambas precisaron obtener el auspicio de principales entidades nacionales y extranjeras; ambas corrían el riesgo de no alcanzar las metas propuestas y por consiguiente dañar la reputación tanto de nuestra Universidad como de nuestro país; ambas requerían el espaldarazo administrativo y el apoyo financiero de la Universidad. Es muy grato casi medio siglo más tarde confirmar que el Instituto naciente pudo enfrentarse exitosamente con cada uno de estos desafíos respaldado lealmente por un Rector que coincidía además con Michael Oakeshott en pensar que la prosecución del saber se asemeja a una conversación ininterrumpida en la que participan todas las disciplinas enriqueciéndose mutuamente y cuyo objeto no puede ser determinado sino por la calidad de los interlocutores. Una conversación es una empresa intelectualmente arriesgada pues así como puede iluminar, también puede aburrir, engañar y decepcionar y vale la pena recordar que en cierta medida el nuevo Instituto se organizó alrededor de seminarios que emulaban las legendarias conversaciones definidas por el gran 
filósofo inglés y derivaban su inspiración y dinamismo del pensamiento de ambos eminentes estudiosos de los clásicos.

\section{Claudio Véliz}

Melbourne, junio de 2011 